\title{
Water Conservation and Nitrogen Loading Reduction Effects with Controlled and Mid-Gathering Irrigation in a Paddy Field
}

\author{
Yuanyuan $\mathrm{Li}^{1,2,3}$, Xiaohou Shao ${ }^{1,2 *}$, Zhuping Sheng ${ }^{3}$, \\ Wenlu Guan ${ }^{1,2}$, Menghua Xiao ${ }^{4}$ \\ ${ }^{1}$ Key Laboratory of Efficient Irrigation-Drainage and Agricultural Soil-Water Environment in Southern China, \\ Hohai University, 210098, China \\ ${ }^{2}$ College of Water Conservancy and Hydropower, Hohai University, Nanjing, 210098, China \\ ${ }^{3}$ Texas AgriLife Research Center at El Paso, Texas A\&M University, 79927, USA \\ ${ }^{4}$ Jiangsu University, Zhenjiang, 212013, China
}

Received: 8 January 2016

Accepted: 17 February 2016

\begin{abstract}
Rice is a widely cultivated crop in China and needs a large quantity of water during its entire growth period. Many water-saving irrigation techniques have been developed and widely applied to conserve water in paddy fields in recent years. A controlled and mid-gathering irrigation (CMI) regime is one of them, of which the main feature is to maximize the use of rainwater different from the others. The objective of this study was to assess and verify the water conservation and nitrogen pollution reduction effects of $\mathrm{CMI}$ in comparison with a conventional irrigation (CVI) regime. Results showed that the CMI method had potential for water conservation by reducing total irrigation amount and irrigation frequency and making better utilization of rainwater during the rice growth stage. By making use of irrigation water more efficiently, CMI showed higher irrigation water use efficiency and rainfall use efficiency. CMI can also reduce nitrogen pollution emitted to the water system by reducing the pollutant discharge rather than the pollutant concentration during a storm event. However, the irrigation regime's effect on pollutant loading reduction was not as significant as fertilizer according to experiment results. Thus, the controlled and mid-gathering irrigation regime was favorable for water conservation and reducing emissions of non-point source pollution.
\end{abstract}

Keywords: water conservation, nitrogen loading, water use efficiency, rainfall use efficiency

*e-mail: shaoxiaohou@163.com 


\section{Introduction}

China is one of the countries facing a severe water crisis. In southern China, the water scarcity caused by the degradation of water environment has become increasingly prominent. Rice is the most widely consumed staple crop in China, which requires support of a great amount of water [1]. In recent years, many water-saving irrigation techniques have been developed to cope with the shortage of water resources in southern China, aiming at achieving the highest possible increase in water use efficiency and rice production [1-6]. For example, shallow wetting irrigation and shallow irrigation combined with timely field drying has shown that the paddy field had more sufficient sunlight than that in flooding irrigation, which could increase final rice yield [7-9]. Alternate furrow irrigation, applying water to one of two continuous furrows, has been applied mainly in arid and semi-arid regions to conserve water and to increase water productivity in agricultural lands [10-12]. Drip irrigation can reduce the irrigation amount without reduction in crop yield and hence increase water use efficiency by delivering water directly to the roots of the crop and reducing evapotranspiration and percolation. It also reduces risks of soil degradation and salinization. It was considered one of the most efficient methods of irrigation, especially in arid and semiarid areas [13-15]. The principal was to apply water regularly to a small volume of soil at a low application rate and at a high frequency to closely meet crop demand [16-19]. Controlled and midgathering irrigation (CMI) is developed from controlled irrigation, a water-saving irrigation technique proposed by Shizhang Peng in Hohai university [20]. In the CMI method, the paddy field surface maintained a water layer of 5-25 $\mathrm{mm}$ after rice seedlings were transplanted based on its characteristics of enduring water but not longtime flooding. After the green-returning stage, both rainfall and soil moisture were considered as the controlling targets to determine the irrigation time and irrigation water quota. Depending on different growth stages of the paddy rice, the upper control limit of soil moisture was the saturated water content during irrigation, while the lower limit was $60-80 \%$ of saturated water content, without a water layer after the green-returning stage. If it rained, the upper limit of rain ceiling storage was controlled at $20-70 \mathrm{~mm}$, according to different growth stages, which was about half of the maximum submergence enduring depth of rice plants. The key difference between CMI and other water-saving irrigation techniques is maximizing the use of natural rainwater.

In addition, nitrogen loss in agricultural drainage and surface runoff waterways are the most important contributors to water quality degradation, especially when there were rain events or even storm drain events. After the heavy rainfall, nutrient loads were rapidly released to water bodies, causing adverse environmental effects thereafter, like eutrophication of urban surface waters and non-point source pollution [21-23]. With CMI, less drainage is expected during the rain, thus reducing water contamination theoretically. However, there are very few studies conducted to quantify such effects. The objective of this study was to evaluate the water conservation and pollution reduction effect under the CMI method in a paddy field.

\section{Materials and Methods}

\section{Experimental Site}

The experiments were carried out at Vegetables (Flowers) Scientific Institute, (latitude $32^{\circ} 13^{\prime} \mathrm{N}$, longitude $\left.119^{\circ} 04^{\prime} \mathrm{E}\right)$, Hengxi Town of Nanjing, Jiangsu Province in China (Fig. 1) during the rice-growing season of 2013-14. The experimental site was located at subtropical humid region, with an average annual rainfall of approximately $1,107 \mathrm{~mm}$ with a rainy season from the end of June to the middle of September. However, average yearly evaporation was around $1,473 \mathrm{~mm}$, with 2,017 sunshine hours, average annual temperature of about $15.7^{\circ} \mathrm{C}$, maximum average humidity of $81 \%$, and average wind speed of $19.8 \mathrm{~m} / \mathrm{s}$.

The pre-experiment analysis showed that paddy field soil was clayey loam, with $\mathrm{pH}$ as 5.87 , bulk density $1.35 \mathrm{~g} \mathrm{~cm}^{-3}$, field capacity $28 \%$, organic matter $21.7 \mathrm{~g} \mathrm{~kg}^{-1}$, hydrolysis nitrogen $86.5 \mathrm{mg} \mathrm{kg}^{-1}$, and available phosphorus (25.3 $\mathrm{mg} \mathrm{kg}^{-1}$ ) at the $0-60 \mathrm{~cm}$ soil layer.

\section{Experimental Design}

The rice (Oriza sativa L. cv. Kaohsiung 139) was grown in completely randomized blocks with a sub-plot size of $10 \mathrm{~m}^{2}$ each, under two irrigation regimes: controlled and mid-gathering irrigation (CMI) and conventional irrigation (CVI), respectively, and treated with three fertilizer levels: low fertilizer (LF), conventional fertilizer (CF), and untreated control (UF). Controlling targets of soil moisture in two irrigation regimes are shown in Table 1. Compound fertilizer was used for both the basal fertilization (during transplanting) and tillering fertilization (about 30 days after transplanting), while urea was used as the panicle fertilization (about 60 days after transplanting). The conventional fertilizer application amount was determined according to local customs, and

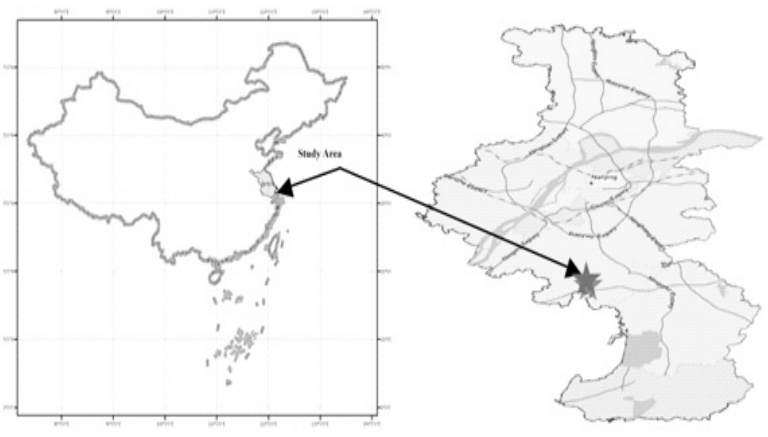

Fig. 1. Map of experimental site in Nanjing, Jiangsu, China. 
Table 1. Controlling targets of soil moisture during paddy rice growth stages in two irrigation regimes.

\begin{tabular}{|c|c|c|c|c|c|c|c|c|}
\hline \multirow{2}{*}{ Treatment } & \multirow{2}{*}{ Returning green } & \multicolumn{3}{|c|}{ Tillering } & \multicolumn{2}{|c|}{ Jointing-Booting } & \multirow{2}{*}{$\begin{array}{l}\text { Heading- } \\
\text { Flowering }\end{array}$} & \multirow{2}{*}{ Milking } \\
\hline & & Early & Mid-term & Late & Early & Late & & \\
\hline CMI & $\begin{array}{l}100 \% \\
(5-25)\end{array}$ & $\begin{array}{c}70 \% \\
(0-50)\end{array}$ & $\begin{array}{c}65 \% \\
(0-50)\end{array}$ & $\begin{array}{l}60 \% \\
(0-0)\end{array}$ & $\begin{array}{c}80 \% \\
(0-70)\end{array}$ & $\begin{array}{c}80 \% \\
(0-70)\end{array}$ & $\begin{array}{c}80 \% \\
(0-70)\end{array}$ & $\begin{array}{c}65 \% \\
(0-20)\end{array}$ \\
\hline CVI & $\begin{array}{c}100 \% \\
(30-50)\end{array}$ & $\begin{array}{l}100 \% \\
(0-30)\end{array}$ & $\begin{array}{c}100 \% \\
(15-30)\end{array}$ & $\begin{array}{l}60 \% \\
(0-0)\end{array}$ & $\begin{array}{c}100 \% \\
(30-50)\end{array}$ & $\begin{array}{c}100 \% \\
(30-50)\end{array}$ & $\begin{array}{c}100 \% \\
(30-50)\end{array}$ & $\begin{array}{c}100 \% \\
(15-30)\end{array}$ \\
\hline
\end{tabular}

Notes: (1) The first number is a percentage of the saturated water content of soil. (2) The numbers in parenthesis are the range of storage depth of surface water in $\mathrm{mm}$ in the paddy field.

the low fertilizer application was $20 \%$ of that amount. All the treatments were replicated three times. Each plot has a separate irrigation water, drainage, water meter, and lysimeter system, but all the plots shared one rain gauge. Polyethylene sheets were applied around the bounds of each plot to prevent lateral seepage loss. Additionally, a measurement zone $(1 \mathrm{~m} \times 1.5 \mathrm{~m} \times 0.8 \mathrm{~m})$ was designed in each plot for observing the ground water level change.

\section{Indicators and Measurements}

Paddy field water content and water depth were measure by TDR and rulers, and rainfall was measured by a rain gauge (SM1-1). Percolation was measured through observation of the measurement zone. Discharge was recorded by water meters installed in each plot.

In this study, three forms of nitrogen pollutants were considered for pollution reduction effect. Following the procedures of the State Environmental Protection Administration (SEPA), total nitrogen (TN) was measured by potassium persulfate oxidation and ultraviolet spectrophotometry, ammonium nitrogen $\left(\mathrm{NH}_{3}-\mathrm{N}\right)$ was measured by Nessler reagent, and nitrate nitrogen (NO-N) was measured by ultraviolet spectrophotometry.

\section{Statistical Analysis}

Data was statistically analyzed using analysis of variance (ANOVA) with SPSS statistical software. ANOVA was performed at $\alpha=0.05$ level of significance to determine if significant differences existed among different irrigation regimes.

\section{Results and Discussions}

\section{Water Conservation \\ Irrigation and Rainfall}

During the whole growth stage of paddy rice, we made statistics about the irrigation and rainfall events (Table 2). As shown in Table 2, the total irrigation frequency for CMI and CVI in 2013 were 10 and 19, and total irrigation amounts were $300 \mathrm{~mm}$ and $570 \mathrm{~mm}$, respectively. While in 2014, the total irrigation frequency for CMI and CVI were 13 and 20, and total irrigation amounts were $480 \mathrm{~mm}$ and $740 \mathrm{~mm}$. Compared to the CVI, the irrigation amount for CMI was $47.4 \%$ and $48.6 \%$ lower, which was significantly reduced.

Table 2. Irrigation and rainfall at each growth stage.

\begin{tabular}{|c|c|c|c|c|c|c|c|}
\hline Year & Treatment & Items & $\begin{array}{l}\text { Returning } \\
\text { green }\end{array}$ & Tillering & Jointing-Booting & Heading-Flowering & Milking \\
\hline \multirow{5}{*}{2013} & \multirow{2}{*}{ CMI } & Irrigation Amount (mm) & 60 & 90 & 60 & 60 & 30 \\
\hline & & Irrigation Frequency & 2 & 3 & 2 & 2 & 1 \\
\hline & \multirow{2}{*}{ CVI } & Irrigation Amount (mm) & 60 & 210 & 150 & 90 & 90 \\
\hline & & Irrigation Frequency & 2 & 7 & 5 & 3 & 3 \\
\hline & CMI\&CVI & Rainfall (mm) & 75.2 & 232.8 & 155.6 & 24.6 & 17.8 \\
\hline \multirow{5}{*}{2014} & \multirow{2}{*}{ CMI } & Irrigation Amount (mm) & 30 & 200 & 90 & 120 & 40 \\
\hline & & Irrigation Frequency & 1 & 5 & 3 & 3 & 1 \\
\hline & \multirow{2}{*}{ CVI } & Irrigation Amount (mm) & 30 & 320 & 150 & 160 & 80 \\
\hline & & Irrigation Frequency & 1 & 8 & 5 & 4 & 2 \\
\hline & CMI\&CVI & Rainfall (mm) & 156.3 & 166.6 & 143.7 & 211.3 & 100.4 \\
\hline
\end{tabular}


Table 3. Water balance in paddy fields.

\begin{tabular}{|c|c|c|c|c|c|c|c|}
\hline \multirow{2}{*}{ Year } & Treatment & $\begin{array}{c}\text { Total Rainfall } \\
(\mathrm{mm})\end{array}$ & $\begin{array}{c}\text { Effective Rainfall } \\
(\mathrm{mm})\end{array}$ & $\begin{array}{c}\text { Irrigation } \\
(\mathrm{mm})\end{array}$ & $\begin{array}{c}\text { Percolation } \\
(\mathrm{mm})\end{array}$ & $\begin{array}{c}\text { Drainage } \\
(\mathrm{mm})\end{array}$ & $\begin{array}{c}\text { RUE } \\
\mathrm{S}(\%)\end{array}$ \\
\hline \multirow{2}{*}{2013} & CMI & 506 & 153.8 & 300 & 238.3 & 203 & $30.4 \mathrm{a}$ \\
\cline { 2 - 9 } & CVI & 506 & 60.2 & 570 & 170.0 & 250 & $11.9 \mathrm{~b}$ \\
\hline \multirow{2}{*}{2014} & CMI & 778.3 & 283.5 & 480 & 370.2 & 300 & $36.4 \mathrm{a}$ \\
\cline { 2 - 9 } & CVI & 778.3 & 81.5 & 740 & 408.5 & 410 & $10.5 \mathrm{~b}$ \\
\hline
\end{tabular}

Notes: There is significant change between lowercase letters ( $a$ and $b$ )

At the returning green stage, the irrigation amount and frequency were the same for both irrigation treatments in both 2013 and 2014. As for tillering, joint-booting, heading-flowering, and milking stages, the irrigation frequency was reduced for the CMI method. The water savings for CMI were $120 \mathrm{~mm}, 90 \mathrm{~mm}, 30 \mathrm{~mm}$, and $60 \mathrm{~mm}$, respectively, compared to CVI in 2013, while it was $120 \mathrm{~mm}, 60 \mathrm{~mm}, 40 \mathrm{~mm}$, and $40 \mathrm{~mm}$ in 2014 . The total irrigation frequency for CMI were 9 and 7 less than that for CVI in 2013 and 2014. We can conclude that the water savings effect was obvious for the CMI regime, the water savings amount was the largest - especially at tillering stage - even though precipitation was high, because the rice consumed much more water at this stage due to fast rice growth.

\section{RUE and WUE}

The total rainfall in 2013 and 2014 was $506 \mathrm{~mm}$ and $778.3 \mathrm{~mm}$. In 2013 it mainly occurred at tillering and joint-booting stages, while in 2014 it concentrated at the tillering and heading-flowering stages. In the CMI method, rainfall was better used, thus much more irrigation water was saved. From Table 3 we can conclude that the rainfall use efficiency (RUE) for CMI was higher than that for CVI. In 2013 and 2014, the RUE for CMI was 2.6 and 3.5 times that for CVI, which illustrated that the CMI regime showed a rather better rainfall use efficiency. The irrigation regimes showed significant effects on RUE.

The irrigation water use efficiency (WUE) of paddy rice in this study was defined as: $W U E=Y / W$, where $Y\left(\mathrm{~kg} \mathrm{~m}^{-2}\right)$ is rice production and $W(\mathrm{~m})$ is the total irrigation water amount. As shown in Table 4, the WUE

Table 4. Water use efficiency in each irrigation method.

\begin{tabular}{|c|c|c|c|c|}
\hline Year & Treatment & $\begin{array}{c}\text { Irrigation } \\
\text { Amount }(\mathrm{mm})\end{array}$ & $\begin{array}{c}\text { Yield } \\
\left(\mathrm{kg} \mathrm{hm}^{-2}\right)\end{array}$ & $\begin{array}{c}\text { WUE } \\
\left(\mathrm{kg} \mathrm{m}^{-3}\right)\end{array}$ \\
\hline \multirow{2}{*}{2013} & CMI & 300 & $6,155.9 \mathrm{a}$ & $2.05 \mathrm{a}$ \\
\cline { 2 - 5 } & CVI & 570 & $6,129.7 \mathrm{a}$ & $1.08 \mathrm{~b}$ \\
\hline \multirow{2}{*}{2014} & CMI & 480 & $8,770.6 \mathrm{a}$ & $1.83 \mathrm{a}$ \\
\cline { 2 - 5 } & CVI & 740 & $\begin{array}{c}8,320.8 \\
\mathrm{ab}\end{array}$ & $1.12 \mathrm{~b}$ \\
\hline
\end{tabular}

Notes: There is significant change between lowercase letters ( $a$ and $b$ ). for CMI was almost twice that for CVI in 2013, while it was a little more in 2014. The irrigation regimes showed a significant effect on WUE. From this table, it also showed that rice production was not reduced with less irrigation water under the CMI regime. The WUE reduced with more irrigation and rainfall in 2014 for the CMI regime, while it was opposite for CVI. That was mainly due to much more water retained in the paddy field during rice growth stages.

a)
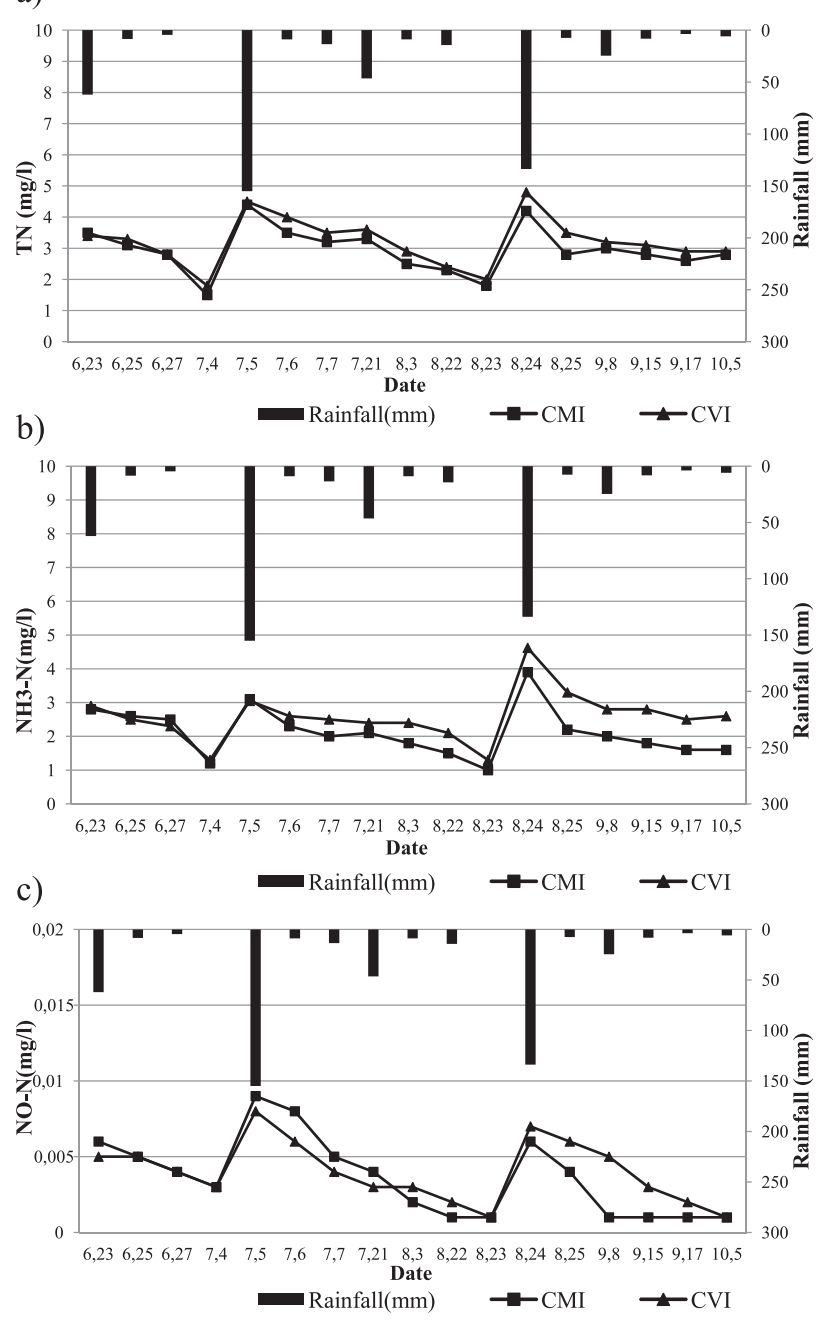

Fig. 2. Nitrogen concentration variations of surface water in the field: a) $\mathrm{TN}(\mathrm{mg} / \mathrm{l})$, b) $\mathrm{NH}_{3}-\mathrm{N}(\mathrm{mg} / \mathrm{l})$ c) $\mathrm{NO}-\mathrm{N}(\mathrm{mg} / \mathrm{l})$. 
Table 5. Estimated pollution loading in each treatment (5 July 2013).

\begin{tabular}{|c|c|c|c|c|c|c|c|}
\hline \multirow{2}{*}{ Treatment } & \multirow{2}{*}{$\begin{array}{c}\text { Discharge } \\
(\mathrm{mm})\end{array}$} & \multicolumn{2}{|c|}{$\mathrm{TN}$} & \multicolumn{2}{|c|}{$\mathrm{NH}-\mathrm{N}$} \\
\cline { 3 - 8 } & $\mathrm{CN}\left(\mathrm{mg} \mathrm{l}^{-1}\right)$ & $\mathrm{TPD}\left(\mathrm{kg} \mathrm{hm}^{-2}\right)$ & $\mathrm{CN}\left(\mathrm{mg} \mathrm{l}^{-1}\right)$ & $\mathrm{TPD}\left(\mathrm{kg} \mathrm{hm}^{-2}\right)$ & $\mathrm{CN}\left(\mathrm{mg} \mathrm{l}^{-1}\right)$ & $\mathrm{TPD}\left(\mathrm{kg} \mathrm{hm}^{-2}\right)$ \\
\hline CMILF & 108 & 3.5 & 3.78 & 2.85 & 3.08 & 0.006 & 0.0065 \\
\hline CVILF & 130 & 3.5 & 4.55 & 3.14 & 4.08 & 0.007 & 0.0091 \\
\hline CMICF & 108 & 4.4 & 4.75 & 3.10 & 3.35 & 0.009 & 0.0097 \\
\hline CVICF & 130 & 4.5 & 5.85 & 3.05 & 3.97 & 0.008 & 0.0104 \\
\hline CMIUF & 108 & 1.5 & 1.62 & 2.15 & 2.32 & 0.002 & 0.0021 \\
\hline CVIUF & 130 & 1.8 & 2.34 & 2.20 & 2.86 & 0.002 & 0.0026 \\
\hline Fertilizer & & $* *$ & $*$ & $*$ & $*$ & $*$ & $*$ \\
\hline Irrigation & & NS & $* *$ & NS & $*$ & NS & NS \\
\hline
\end{tabular}

Notes: 1. CN is short for concentration, and TPD is short for total pollution discharge. 2. According to ANOVA,

there was no significance (NS) at $\mathrm{P}>0.05$ and significant differences $(*)$ at $\mathrm{P} \leq 0.05$, while there was extremely significant difference $(* *)$ at $\mathrm{P} \leq 0.01$ at $\alpha=0.05$ level.

Table 6. Estimated pollution loading in each treatment (24 August 2013).

\begin{tabular}{|c|c|c|c|c|c|c|c|}
\hline \multirow{2}{*}{ Treatment } & \multirow{2}{*}{$\begin{array}{c}\text { Discharge } \\
(\mathrm{mm})\end{array}$} & \multicolumn{2}{|c|}{ TN } & \multicolumn{2}{|c|}{ NH3-N } & \multicolumn{2}{c|}{ NO-N } \\
\cline { 3 - 8 } & $\mathrm{CN}\left(\mathrm{mg} \mathrm{l}^{-1}\right)$ & $\mathrm{TPD}\left(\mathrm{kg} \mathrm{hm}^{-2}\right)$ & $\mathrm{CN}\left(\mathrm{mg} \mathrm{l}^{-1}\right)$ & $\mathrm{TPD}\left(\mathrm{kg} \mathrm{hm}^{-2}\right)$ & $\mathrm{CN}\left(\mathrm{mg} \mathrm{l}^{-1}\right)$ & $\mathrm{TPD}\left(\mathrm{kg} \mathrm{hm}^{-2}\right)$ \\
\hline CMILF & 95 & 4.1 & 3.9 & 4.01 & 3.81 & 0.006 & 0.0057 \\
\hline CVILF & 120 & 4.2 & 5.04 & 4.07 & 4.88 & 0.006 & 0.0072 \\
\hline CMICF & 95 & 4.2 & 3.99 & 3.90 & 3.71 & 0.006 & 0.0057 \\
\hline CVICF & 120 & 4.8 & 5.76 & 4.62 & 5.54 & 0.007 & 0.0084 \\
\hline CMIUF & 95 & 2.3 & 2.19 & 2.22 & 2.11 & 0.002 & 0.0019 \\
\hline CVIUF & 120 & 2.1 & 2.52 & 2.05 & 2.46 & 0.002 & 0.0024 \\
\hline Fertilizer & & $*$ & NS & $*$ & NS & $*$ & $*$ \\
\hline Irrigation & & NS & NS & NS & NS & NS & NS \\
\hline
\end{tabular}

Notes: 1. CN is short for concentration, and TPD is short for total pollution discharge. 2. According to ANOVA, there was no significance(NS) at $\mathrm{P}>0.05$ and significant differences $(*)$ at $\mathrm{P} \leq 0.05$, while there was extremely significant difference (**) at $\mathrm{P} \leq 0.01$ at $\alpha=0.05$ level.

From Table 3, the drainage for CMI was $47 \mathrm{~mm}$ and $90 \mathrm{~mm}$ lower than that for CVI in 2013 and 2014. The reducing proportion was $18.8 \%$ and $30 \%$, respectively, which was favorable for reducing paddy field runoff, resulting in pollution loading reduction discussed in the following section.

In summary, from the results obtained above, CMI had great water conservation potential without yield reduction compared to the CVI regime through the highly efficient use of rainwater and less drainage from the paddy field.

\section{Nitrogen Loading Reduction}

\section{Nitrogen Concentration Variations in Field Surface Water}

In 2013, two storm events occurred (on 4 July and 23 August) during the whole growth period of paddy rice. Since nitrogen loading was one of the leading elements in agriculture non-point source pollution, we took consideration of three forms of nitrogen pollutant, total nitrogen $(\mathrm{TN})$, ammonium nitrogen $\left(\mathrm{NH}_{3}-\mathrm{N}\right)$, and nitrate nitrogen (NO-N). As shown in Fig. 2, the concentrations of $\mathrm{TN}, \mathrm{NH}_{3}-\mathrm{N}$, and $\mathrm{NO}-\mathrm{N}$ were reduced to a rather lower level, and then increased significantly on the next day. That was because of a big storm event, and then drainage occurred according to the water-controlling targets in Table 1.

When field drainage occurred the day after the rain, the concentration of $\mathrm{TN}$ and $\mathrm{NH}_{3}-\mathrm{N}$ for $\mathrm{CMI}$ in surface water of the paddy field was lower compared to CVI on 5 July and 24 August, and it decreased dramatically with time. However, the concentration of NO-N for CMI was higher than that for CVI at the beginning. Overall, the trends of changes in nitrogen concentration for CMI and CVI were pretty much the same, i.e., decreasing with time when there was no drainage process. According to CMI, much more water was retained in the paddy field, thus the concentration was lower than CVI most of the time. 
Table 7. Average pollutant loading in certain water or fertilizer conditions.

\begin{tabular}{|c|c|c|c|c|c|c|c|}
\hline \multicolumn{2}{|c|}{ Treatment } & \multicolumn{2}{c|}{$\mathrm{TN}\left(\mathrm{kg} \mathrm{hm}^{-2}\right)$} & \multicolumn{2}{c|}{$\mathrm{NH}_{3}-\mathrm{N}\left(\mathrm{kg} \mathrm{hm}^{-2}\right)$} & \multicolumn{2}{c|}{ NO-N $\left(\mathrm{kg} \mathrm{hm}^{-2}\right)$} \\
\cline { 2 - 8 } \multicolumn{2}{|c|}{} & $5 \mathrm{July}$ & 24 Aug. & 5 July & 24 Aug. & 5 July & 24 Aug. \\
\hline \multirow{3}{*}{ Water } & CMI & 3.38 & 3.95 & 2.92 & 3.76 & 0.0061 & 0.0057 \\
\cline { 2 - 8 } & CVI & 4.25 & 5.40 & 3.64 & 5.21 & 0.0074 & 0.0078 \\
\hline \multirow{3}{*}{ Fertilizer } & LF & 4.17 & 4.47 & 3.58 & 4.35 & 0.0078 & 0.0065 \\
\cline { 2 - 8 } & CF & 5.30 & 4.88 & 3.66 & 4.63 & 0.0101 & 0.0071 \\
\cline { 2 - 8 } & UF & 1.98 & 2.36 & 2.59 & 2.29 & 0.0024 & 0.0022 \\
\hline
\end{tabular}

\section{Nitrogen Loading}

After the storm events, drainage occurred through the drainage pipe in the paddy field. The discharge was measured by water meter and then converted to water depth over the field. Since the drainage in the paddy field was a continuous process and pollutant concentration in discharge varied with time, the pollution loading was only estimated with the average discharge and instant pollutant concentration. The estimated pollutant loading is shown in Table 5 and Table 6.

As shown in Tables 5 and 6, the total discharge was $108 \mathrm{~mm}$ and $95 \mathrm{~mm}$ for CMI, while it was $130 \mathrm{~mm}$ and $120 \mathrm{~mm}$ for CVI, respectively. Thus under the CMI regime, more rainwater was retained in the paddy field. Less discharge of the polluted water resulted in less pollutant loading into the river, in turn promoting protection of the water environment.

According to the analysis of variance (ANOVA) of the two drainage processes, the fertilizer effect was significant to $\mathrm{TN}$ and $\mathrm{NH}_{3}-\mathrm{N}$ concentrations, whereas it showed no significance to total $\mathrm{TN}$ and $\mathrm{NH}_{3}-\mathrm{N}$ discharge. As for the irrigation effect, it showed significance to $\mathrm{TN}$ and $\mathrm{NH}_{3}-\mathrm{N}$ concentrations for both drainage processes, while it was significant to $\mathrm{TN}$ and $\mathrm{NH}_{3}-\mathrm{N}$ discharge on 5 July, but no significance on 24 August. That was mainly due to water discharge reduction on 24 August, resulting in lower irrigation and fertilizer effects on total pollution discharge.

As for NO-N, the fertilizer and irrigation effects were the same for both drainage processes. The fertilizer showed significance for both the concentration and total discharge, while the irrigation showed no significance for NO-N concentration and total discharge. That was due to low NO-N content in the discharge.

As shown in Table 7, $\mathrm{NH}_{3}-\mathrm{N}$ was the main form of nitrogen loss in drainage, while NO-N content was very low to negligible. The results showed that the averaged pollutant loadings were different for two different irrigation regimes. For CVI, the loading of all nitrogen was higher for both storm events than those for CMI. The averaged TN loading for CVI was $25.7 \%$ and $36.7 \%$ more than those for CMI. The averaged $\mathrm{NH}_{3}-\mathrm{N}$ and $\mathrm{NO}-\mathrm{N}$ for CVI were $24.7 \%$ and $38.6 \%$ - or $11.5 \%$ and $36.8 \%$ more, respectively. It is also clear that higher fertilizer applications result in more nitrogen pollution loading (conventional $>$ lower $>$ no fertilizer treatments as shown in Table 7).

\section{Limitations}

In this study, nitrogen loading was estimated with the average discharge and instant pollutant concentration, thus the data obtained may vary during the confirmatory test. It is also important to note that the pollution reduction effect was evaluated only based on the data of the one-year experiment. Hence, further extended studies are recommended to account for the results obtained in this study.

\section{Discussion}

The results presented above focus mainly on the effect of the CMI method on paddy field water quality and water conservation. However, the interaction between CMI and fertilizer amount as well as its type has not been well understood, and has not been studied before. Since the CMI was favorable for both crop growth and environmental protection, it is important to conduct further studies on such interaction.

In this study the pollutant concentration was not monitored over the time of drainage. It is recommended that the water quality be monitored during the drainage processes of storms. In addition, numerical models could be developed to simulate the nutrients' dynamic changes under the rainfall and fertilizer conditions during all growth stages of rice.

\section{Conclusions}

1. As demonstrated by this study, total irrigation amount and irrigation frequency for CMI was less than the CVI method. The CMI could make a better utilization of rainfall, thus it had a great water conservation potential while rice yield was not reduced compared to the CVI method.

2. During the drainage process, the discharge amount of nitrogen for CMI was lower than that for CVI, and $\mathrm{NH}_{3}-\mathrm{N}$ was the main form of nitrogen loss. In the whole growth stage of paddy rice, nitrogen concentration decreased with time except for the big rain event that happened.

3. As for pollutant (TN, $\mathrm{NH}_{3}-\mathrm{N}$ and NO-N) concentrations, fertilizer factor showed significant effect, 
while irrigation factor showed no significance. For pollutant discharge, it was not consistent according to the different drainage processes. The less the water discharge was, the smaller the effects on pollutant discharge.

\section{Acknowledgements}

This work was funded by the Research Project of Special Scientific Funds in Public Service Sectors (Water Conservancy) (201301017), the Fundamental Research Funds for Central Universities (2014B37714, 2014B04814, 2015B05814), the Science and Technology Project of Jiangsu Province (BE2015705), the Water Conservancy Science and Technology Project of Jiangsu Province $(2013073$, 2014049), the National Natural Science Fund (No. 51409124), and the Natural Science Foundation of Jiangsu Province (No. BK20140564).

Also, the first author thanks the China Scholarship Council for its support to allow the author to conduct collaborative research at the Texas A\&M AgriLife Research Center. The first and third authors also appreciate the support in part by the National Institute of Food and Agriculture (NIFA) Hatch Project (1007968) of the United States Department of Agriculture.

\section{References}

1. XING W.G., SUN L., YU S.E., SHAO G.C., KANG G.L., GUO C. Effect of underground water level on physiological growth index in paddy rice heading and flowering stage. Yellow River. 1, 85, 2011.

2. LI,Y., SHAO X., TAN J., HU X., ZHOU J., WANG J., LU S., XU H. Effects of controlled and mid-gathering irrigation on paddy rice height and yield. Journal of Food, Agriculture \& Environment. 10 (3-4), 659, 2012.

3. XIAO X., YU S.E., ZHAO W. Benefit analysis of popularization of water-saving irrigation techniques for paddy planting in Jiangsu Province. Adv. Sci. and Technol. Water Resources. 25, 39, 2005.

4. BELDER P., BOUMAN B.A.M., CABANGON R., GUOAN LU, QUILANG E.J.P., LI YUANHUA J.H.J., SPIERTZ T.P. Effect of water saving irrigation on rice yield and water use in typical lowland conditions in Asia. Agric. Water Manage. 65, 193, 2004.

5. MGUIDICHE A., PROVENZANO G., DOUH B., KHILA S., RALlO G., BOUJELBEN A. Assessing Hydrus-2D to simulate soil water content (SWC) and salt accumulation under an SDI system: Application to a potato crop in a semiarid area of central TUNISIA. Irrigation and Drainage. 64, 263, 2015.

6. BELDER P., SPIERTZ J.H.J., BOUMAN B.A.M., LU G., TUONG T.P. Nitrogen economy and water productivity of lowland rice under water-saving irrigation. Field Crops Research, 93, 169, 2005.

7. XIE L., LI G. Study of integrated water-saving irrigation technology on paddy rice. Hunan Hydro\& Power. 1, 25, 2002.

8. WANG Y., WANG S. Discussion on water-saving technology effect of paddy rice. Anhui Agriculture. 2, 153, 2008.

9. MA Y., WANG S. Analysis for factors affecting rice yield. Jilin Water Resources. 7, 61, 2010.
10. HAMED EBRAHIMIAN, ABDOLMAJID LIAGHAT, MASOUD PARSINEJAD, ENRIQUE PLAYAN, FARIBORZ ABBASI, MARYAM NAVABIAN. Simulation of $1 \mathrm{D}$ surface and 2D subsurface water flow and nitrate transport in alternate and conventional furrow fertigation. Irrig Sci. 31, 301, 2013.

11. SLATNI A., ZAYANI K., ZAIRI A., YACOUBI S., SALVADOR R., PLAYA'N E. Assessing alternate furrow strategies for potato at the Cherfech irrigation district of Tunisia. Biosyst Eng. 108 (2), 154, 2011.

12. THIND H.S., BUTTAR G.S., AUJLA M.S. Yield and water use efficiency of wheat and cotton under alternate furrow and check-basin irrigation with canal and tube well water in Punjab, India. Irrigation Sci. 28, 489, 2010.

13. LIU M., YANG J., LI X., LIU G., YU M., WANG J. Distribution and dynamics of soil water and salt under different drip irrigation regimes in northwest China. Irrig Sci. 31, 675, 2013.

14. KANDELOUS M.M., SIMUNEK J. Numerical simulations of water movement in a subsurface drip irrigation system under field and laboratory conditions using HYDRUS-2D. Agric Water Manag. 97, 1070, 2010.

15. KARLBERG L., FRITS W.T.P.V. Exploring potentials and constraints of low-cost drip irrigation with saline water in sub-Saharan Africa. Phys Chem Earth. 29, 1035, 2004.

16. PHOGAT V., SKEWES M.A., COX J.W., SANDERSON G., ALAM J., ŠIMUNEK J. Seasonal simulation of water, salinity and nitrate dynamics under drip irrigated mandarin (Citrus reticulata) and assessing management options for drainage and nitrate leaching. Journal of Hydrology. 513, $504,2014$.

17. VINICIUS BOF BUFON, ROBERT J. LASCANO, CRAIG BEDNARZ, JILL D. BOOKER, DENNIS C. GITZ. Soil water content on drip irrigated cotton: comparison of measured and simulated values obtained with the Hydrus 2-D model. Irrig Sci. 30, 259, 2012.

18. ZHOU Q., KANG S., ZHANG L., LI F. Comparison of APRI and Hydrus-2D models to simulate soil water dynamics in a vineyard under alternate partial root zone drip irrigation. Plant Soil. 291, 211, 2007.

19. AJDARY K., SINGH D.K., SINGH A.K., KHANNA M. M odelling of nitrogen leaching from experimental onion field under drip fertigation. Agricultural Water Management. 89, $15,2007$.

20. PENG S. Controlled irrigation technique of water-saving and high yield rice. Advances in Science and Technology of Hohai University. 11 (4), 75, 1991.

21. BENJAMIN D. JANKE, JACQUES C. FINLAY, SARAH E. HOBBIE, LARRY A. BAKER, ROBERT W. STERNER, NIDZGORSKI D., BRUCE N. WILSON. Contrasting influences of stormflow and baseflow pathways on nitrogen and phosphorus export from an urban watershed. Biogeochemistry. 121, 209, 2014.

22. DUBROVSKY N.M., BUROW K.R., CLARK G.M., GRONBERG J.M., HAMILTON P.A., HITT K.J., MUELLER D.K., MUNN M.D., NOLAN B.T., PUCKETT L.J., RUPERT M.G., SHORT T.M., SPAHR N.E., SPRAGUE L.A., WILBER W.G. The quality of our Nation's waters - Nutrients in the Nation's streams and groundwater, 1992-2004: US Geol Survey Circular 1350, 174, 2010.

23. VANDER KAUFMANN, ADILSON PINHEIRO, NILZA MARIA DOS REIS CASTRO. Simulating transport of nitrogen and phosphorus in a Cambisol after natural and simulated intense rainfall. Journal of Contaminant Hydrology. 160, 53, 2014. 